Article

\title{
Improved Food Waste Stabilization and Valorization by Anaerobic Digestion Through Supplementation of Conductive Materials and Trace Elements
}

\author{
A. Sinan Akturk ${ }^{1}$ and Goksel N. Demirer ${ }^{1,2, *}$ \\ 1 School of Engineering and Technology, Central Michigan University, Mt. Pleasant, MI 48859, USA; \\ aktur1s@cmich.edu \\ 2 Institute for Great Lakes Research, Central Michigan University, Mt. Pleasant, MI 48859, USA \\ * Correspondence: demir1g@cmich.edu; Tel.: +001-989-774-2456
}

Received: 25 May 2020; Accepted: 25 June 2020; Published: 26 June 2020

\begin{abstract}
The positive effects of conductive material supplementation on anaerobic digestion have been mainly investigated for single synthetic substrates, while its significance for real and complex organic wastes such as food waste has not been sufficiently investigated. This study investigated the effect of conductive material (biochar and magnetite) and trace metal supplementation on the anaerobic digestion of food waste by means of biochemical methane potential assays. The results indicated that the supplementation of biochar and trace metals improved both total biogas production and methane yields. A biochar dose of 2.0 and $5.0 \mathrm{~g} / \mathrm{L}$ resulted in $11.2 \pm 6.5$ and $27.3 \pm 9.5 \%$ increase in biogas and $8.3 \pm 6.8$ and $33.2 \pm 2.8 \%$ increase in methane yield, respectively. Moreover, the same reactors demonstrated high food waste stabilization performance of over $80 \%$ chemical oxygen demand removal efficiency. These results indicate that biochar supplementation leads to more enhanced anaerobic digestion operation that could be through increased surface area for microbial growth and/or direct interspecies electron transfer mechanism. In turn, food waste will not only be stabilized but also valorized by anaerobic digestion at higher efficiencies that support sustainable waste management through both environmentally safe disposal and value-added generation.
\end{abstract}

Keywords: anaerobic digestion; food waste; direct interspecies electron transfer (DIET); biochar

\section{Introduction}

Sustainability calls for achieving closed-loop systems to maximize the recovery of bioenergy and bio-based materials derived from the waste at end-of-life. Therefore, waste should be considered as "renewable resources" that can be used again to generate valuable and marketable products, replacing the non-renewable fossil-based resources.

Food waste (FW) is not only a very significant environmental problem but also presents ample opportunities for valorization. About one-third of all food produced worldwide in 2011-some 1.7 billion tons/year-is lost or wasted along the food value chain [1]. This amount is comparable to the total agricultural production (for food and non-food uses), which is about 6 billion tons. In developing countries, this wastage occurs mainly in the post-harvest phase due to lack of adequate infrastructure, while in developed countries wastage occurs mainly at the retail and consumption levels due to overly constraining regulations and unsustainable consumption patterns [1,2].

The carbon footprint of wasted food is estimated to be 3.3 billion tons of $\mathrm{CO}_{2}$ equivalent [2]. Globally, the blue water footprint (i.e. the consumption of surface and groundwater resources) of food wastage is about $2.5 \times 10^{11} \mathrm{~m}^{3}$, which is equivalent to the annual water discharge of the Volga river, or three times the volume of Lake Geneva. Finally, produced but uneaten food occupies almost 1.4 billion hectares of land; this represents close to 30 percent of the world's agricultural land area [2]. 
The reduction of food wastage at all levels of value chain is the optimal approach to deal with this problem. However, there will be a significant FW generation for a quite while even with better management practices of source reduction. The landfilling of FW has been banned in most developed countries, leaving incineration as the preferred method [3]. Considering the adverse environmental impacts of the incineration and composting of FW [4,5], its valorization represents an opportunity not only to mitigate the relevant environmental impacts but also to generate value added products [6-8].

Anaerobic digestion (AD) of organic wastes is not only a waste management but also waste valorization technique which offers energy recovery, nutrient reclamation as well as bio-based product generation [9-13].

FW can originate both from the food processing industry as residue and wasted food from residential and commercial activities. It is characterized as easily biodegradable substrate with a low $\mathrm{pH}$ and a very high organic and moisture content. Due to the wide range of sources and types, the composition of FW is very variable both in time and space. These properties make the AD of FW a continuing challenge. Pre-treatment, co-digestion, improving reactor configurations and operational conditions (e.g. temperature, retention time, and recirculation) are the most widely investigated methods to improve the AD and thus the biogas production from FW [14-16]. FW contains high levels of easily degradable carbohydrates which may result in the accumulation of volatile fatty acids (VFAs) due to unbalance of the acidogenesis/acetogenesis and methanogenesis steps [3,9,15-17]. This leads to rapid acidification, that is one of the main causes of process failure during the AD of FW.

The problem of VFA accumulation thus rapid acidification can be overcome by the direct interspecies electron transfer (DIET) mechanism which can be facilitated by conductive material (biochar, magnetite, granular activated carbon, etc.) supplementation. DIET is a more effective mechanism for interspecies electron exchange under anaerobic conditions than interspecies electron transfer (IIET) via reduced molecules such as hydrogen and formate [18]. Conductive material (biochar, magnetite, granular activated carbon, etc.) supplementation to AD may facilitate DIET that has been considered as an alternative to indirect interspecies electron transfer (IIET) via hydrogen and formate transfer [18]. DIET is an alternative to IIET in which the electrons are transferred between the electron-donor and acceptors. DIET is a faster and more efficient electron transfer mechanism than IIET $[18,19]$. Moreover, the degradation of VFAs during AD is thermodynamically dependent of the concentrations of hydrogen or formate [20]. Thus, the application of conductive materials to favor DIET and thus avoid VFA accumulation during AD of high-strength and complex substrates (such as FW) could significantly elevate the existing benefits of AD. For example, it was already shown that conductive materials could enhance the syntrophic transformation of alcohols and VFA to methane through DIET by means of co-cultures of G. metallireducens and Methanosarcina barkeri $[21,22]$ and mixed cultures $[18,23]$. It was indicated that while DIET is an efficient electron transfer pathway compared with IIET, its potential positive effects on AD were mainly investigated for single synthetic substrates (such as acetate, propionate, butyrate, etc.), while its significance for real and complex organic wastes such as FW was not sufficiently investigated [24,25].

Syntrophic hydrogenotrophic methanogenesis requires the synthesis of enzymes, particularly for the production of formate dehydrogenase for formate cleavage [26]. This process requires the presence of trace metals (iron, selenium, cobalt, molybdenum, nickel, tungsten, etc.) in the system. The essential metals for $\mathrm{AD}$ include nickel (Ni), cobalt (Co), molybdenum (Mo), iron (Fe), selenium $(\mathrm{Se})$, and tungsten $(\mathrm{W})$ for methanogens, and zinc $(\mathrm{Zn})$, copper $(\mathrm{Cu})$, and manganese $(\mathrm{Mn})$ for the hydrolytic bacteria [27]. A deficiency of these essential elements may affect the functions and activities of key enzymes, and change the environmental conditions, such as the oxidative-reductive potential, for microbial growth [27], and result in digester failure, e.g., caused by excessive accumulation of VFAs and ammonia. Thus, trace metal supplementation is another approach to reduce VFA accumulation during the AD of FW since it contains low concentrations of trace metals [26,28,29]. 
The objective of this study was to investigate the effect of conductive material (biochar and magnetite) and trace metal supplementation on the AD performance of FW by means of biochemical methane potential (BMP) assays.

\section{Materials and Methods}

\subsection{Anaerobic Seed}

Anaerobic seed was obtained from the anaerobic digester of Michigan State University in East Lansing, Michigan. It was kept undisturbed at ambient temperature for starvation and solids settling. The supernatant was discarded, and the remaining sludge was used as anaerobic seed for BMP tests. The seed had a total and volatile solid (TS and VS) concentration of 33,500 \pm 300 and 21,400 $\pm 200 \mathrm{mg} / \mathrm{L}$, respectively. The total chemical oxygen demand (COD) concentration of the seed was measured as $8883 \pm 46 \mathrm{mg} / \mathrm{L}$ (Table 1).

Table 1. Characterization of microalgal biomass, food waste and anaerobic seed samples.

\begin{tabular}{cccc}
\hline \multirow{2}{*}{ Parameter } & \multirow{2}{*}{ Seed } & \multicolumn{2}{c}{ Food Waste } \\
\cline { 3 - 4 } & & First Exp. Setup & Second Exp. Setup \\
\hline COD (mg/L) & $8883 \pm 46$ & $91,455 \pm 12,065$ & $62810 \pm 7710$ \\
TS (mg/L) & $33,500 \pm 300$ & $118,700 \pm 7700$ & $77,200 \pm 2500$ \\
VS (mg/L) & $21,400 \pm 200$ & $111,900 \pm 7200$ & $71,500 \pm 2700$ \\
Total N (mg/L) & $265 \pm 66$ & $561 \pm 66$ & $595 \pm 85$ \\
Total P (mg/L) & $686 \pm 140$ & $464 \pm 127$ & $1792 \pm 78$ \\
pH & 8.9 & 4.2 & 6.3 \\
\hline
\end{tabular}

Notes: COD: Chemical oxygen demand; TS: Total solids; VS: Volatile solids;.N: Nitrogen; P: Phosphorus.

\subsection{Food Waste}

FW was collected from Central Michigan University's (CMU) campus. It was mixed to achieve a homogenous mixture and the ingredients were blended until a slurry was formed. The slurry was refrigerated at $4{ }^{\circ} \mathrm{C}$ prior to characterization and BMP assays. Total chemical oxygen demand (COD) of food waste slurry was $62,810-91,455 \mathrm{mg} / \mathrm{L}$, with total solids (TS) and volatile solids (VS) contents that were 77,200-118,700 and 71,500-111,900 mg/L, respectively (Table 1). The FW samples for the first and second experimental setup were collected from the resident halls and a restaurant in CMU campus, respectively. The difference in the characterization of the FW samples (Table 1) was due to different sources of collection.

\subsection{Conductive Material}

The biochar was made from dried wastewater biosolids (i.e., Milorganite) composed of raw waste activated sludge and anaerobically digested primary sludge at the water resource reclamation facility in Milwaukee, WI (Jones Island WRRF). The dried biosolids were pyrolyzed at $700{ }^{\circ} \mathrm{C}$ for $15 \mathrm{~min}$ in a rotary pyrolyzer at Norris Thermal Technologies, Tippecanoe, IN. High purity ( $>99.9 \%)$ synthetic magnetite fine black powder $(2-4 \mu \mathrm{m})$ was obtained from MiniScience Inc., Clifton, $\mathrm{NJ}$.

\subsection{Analytical Methods}

Standard methods have been followed for total solids (2540 B) and volatile solids (2540 E) [30]. Chemical oxygen demand (HACH/EPA Method 8000), total nitrogen (HACH/EPA Method 10072) and Total phosphorus (HACH/EPA Method 8190) were conducted by using Hach test kit vials (Hach, Loveland, CO, USA). During the BMP assays, biogas production in each reactor was measured by the water displacement method [31].

Biogas composition was quantified using a gas chromatography (GC) device (SRI Instruments, 310C, CA, USA) equipped with flame-ionization detector (FID) and packed column HayeSep D 
(Agilent, 80/100, 1/8, $2 \mathrm{~mm}$ ) to detect $\mathrm{CH}_{4}$ content. The temperatures of the oven, injector, and detector were maintained at $150{ }^{\circ} \mathrm{C}$. Helium was employed as a carrier gas at a constant pressure of 21 psi. All quantifications were performed in triplicates.

\subsection{Biochemical Methane Potential Assays}

Batch reactors with $250 \mathrm{~mL}$ volumes were operated to determine the anaerobic degradability and biogas production potential of the FW samples with and without conductive materials and trace metals.

The first experimental setup was run to determine the effect of biochar $(20 \mathrm{~g} / \mathrm{L})$ and trace metals on the AD of FW. Four control (seed and FW) and four test (seed, FW, biochar and/or trace metals) reactors were run in triplicates (Table 2). All reactors contained $4280 \mathrm{mg} / \mathrm{L}$ anaerobic seed as VS and $6000 \mathrm{mg} / \mathrm{L} \mathrm{NaHCO}_{3}$ as alkalinity source. The effect of biochar was investigated in the absence (T1 and T3) and presence (T2 and T4) of trace metals (Table 2). The trace metal solution contained $100 \mathrm{mg} / \mathrm{L}$ $\mathrm{FeCl}_{2} ; 4 \mathrm{H}_{2} \mathrm{O}, 20 \mathrm{mg} / \mathrm{L} \mathrm{CoCl}{ }_{2} ; 6 \mathrm{H}_{2} \mathrm{O}, 20 \mathrm{mg} / \mathrm{L} \mathrm{NiCl}_{2} ; 6 \mathrm{H}_{2} \mathrm{O}, 2 \mathrm{mg} / \mathrm{L} \mathrm{CuCl}_{2} ; 2 \mathrm{H}_{2} \mathrm{O}, 2 \mathrm{mg} / \mathrm{L} \mathrm{ZnCl} 2,6 \mathrm{mg} / \mathrm{L}$ $\mathrm{Na}_{2} \mathrm{MoO}_{4} ; 2 \mathrm{H}_{2} \mathrm{O}$, and $2 \mathrm{mg} / \mathrm{L} \mathrm{NaWO} ; 2 \mathrm{H}_{2} \mathrm{O}$. Two different COD concentrations were tested in the first experimental setup, namely, 4520 (C1, C2, T1, and T2) and $7264 \mathrm{mg} / \mathrm{L}(\mathrm{C} 3, \mathrm{C} 4, \mathrm{~T} 3$, and T4).

Table 2. The experimental setups and biogas production observed in reactors.

\begin{tabular}{ccccc}
\hline & Reactor & Trace Metals & Biochar $(\mathrm{g} / \mathrm{L})$ & Magnetite $(\mathrm{g} / \mathrm{L})$ \\
\hline & C1 & - & 0 & 0 \\
& C2 & + & 0 & 0 \\
& T1 & - & 20 & 0 \\
First Experimental Setup & T2 & + & 20 & 0 \\
& C3 & - & 0 & 0 \\
& C4 & + & 0 & 0 \\
& T3 & - & 20 & 0 \\
& T4 & + & 20 & 0 \\
Second Experimental Setup & C5 & + & 0 & 0 \\
& T5 & + & 2.0 & 0 \\
& T6 & + & 5.0 & 0 \\
& T7 & + & 10.0 & 0 \\
& T8 & + & 0 & 2.0 \\
& T9 & + & 0 & 5.0 \\
& T10 & + & 0 & 10.0 \\
\hline
\end{tabular}

After observing the positive impact of biochar supplementation in the first setup, the second experimental setup was run to observe the effect of lower range of biochar and magnetite doses $(2.0-10.0 \mathrm{~g} / \mathrm{L}$ ) in the presence of trace metals. Blank (seed but no FW), control (seed and FW) and six test (seed, FW, trace metals, biochar or trace metals) reactors were run in triplicates (Table 2). All reactors contained $2853 \mathrm{mg} / \mathrm{L}$ anaerobic seed as VS and $6000 \mathrm{mg} / \mathrm{L} \mathrm{NaHCO}_{3}$ as alkalinity source. The effect of 2.0, 5.0, and $10.0 \mathrm{~g} / \mathrm{L}$ biochar supplementation was investigated with reactors T5, T6 and $\mathrm{T} 7$, respectively. While, the effect of 2.0, 5.0 , and $10.0 \mathrm{~g} / \mathrm{L}$ magnetite supplementation was investigated with test reactors T8, T9 and T10, respectively (Table 2). All the reactors received trace metal solution identical to the first experimental setup. The COD concentration in all reactors was $7467 \mathrm{mg} / \mathrm{L}$.

After addition of all the constituents, $\mathrm{pH}$ values of the reactors were adjusted to $7.1 \pm 0.2$ by $2 \mathrm{~N} \mathrm{HCl}$ and $\mathrm{NaOH}$ solutions. Reactors were purged with $\mathrm{N}_{2}$ gas for 4 minutes and capped with rubber septa. Immediately after purging, the reactors were incubated in an environmental chamber at $35 \pm 1{ }^{\circ} \mathrm{C}$ with constant mixing at $120 \mathrm{rpm}$. The daily gas production was measured, and the gas compositions were analyzed. 


\section{Results and Discussion}

\subsection{Biogas Production}

The methane $\left(\mathrm{CH}_{4}\right)$ contents of the biogas produced in reactors were determined on Days 42 and 34 for the first and second experimental setups. The average methane content ranged between $41.0 \pm 1.8$ and $68.1 \pm 0.9 \%$ (Table 3). Biogas production was observed in all reactors at different levels, which was based on initial COD concentrations as well as biochar, magnetite and trace metals supplementation (Figures 1-3).

Table 3. Methane yield observed in reactors.

\begin{tabular}{cccccc}
\hline Reactor & \multicolumn{3}{c}{ Biogas Production } & \multicolumn{2}{c}{ Methane Yield } \\
\cline { 2 - 5 } & $\begin{array}{c}\text { Methane } \\
\text { Content (\%) }\end{array}$ & Volume (mL) & $\begin{array}{c}\text { Change } \\
\text { Relative to } \\
\text { Control (\%) }\end{array}$ & mL CH $/$ /g VS & $\begin{array}{c}\text { Change } \\
\text { Relative to } \\
\text { Control (\%) }\end{array}$ \\
\hline C1 & $45.6 \pm 6.8$ & $245.8 \pm 40.0$ & - & $293.0 \pm 12.0$ & - \\
C2 & $41.0 \pm 1.8$ & $226.8 \pm 10.2$ & - & $238.4 \pm 5.2$ & - \\
T1 & - & $209.2 \pm 2.0$ & $-12.7 \pm 18.9$ & - & - \\
T2 & - & $160.9 \pm 26.2$ & $-29.4 \pm 11.8$ & - & - \\
C3 & $60.8 \pm 2.0$ & $441.4 \pm 12.6$ & - & $372.0 \pm 6.8$ & - \\
C4 & $64.0 \pm 0.3$ & $436.2 \pm 32.6$ & - & $386.4 \pm 12.3$ & - \\
T3 & $55.6 \pm 6.9$ & $460.6 \pm 16.3$ & $4.3 \pm 1.0$ & $358.5 \pm 21.2$ & $-3.7 \pm 5.6$ \\
T4 & $58.5 \pm 0$ & $400.9 \pm 98.7$ & $-9.3 \pm 22.4$ & $386.6 \pm 16.8$ & $0.0 \pm 1.6$ \\
C5 & $65.5 \pm 0.6$ & $241.4 \pm 31.0$ & - & $408.9 \pm 21.2$ & - \\
T5 & $63.7 \pm 0.5$ & $267 \pm 23.3$ & $11.2 \pm 6.5$ & $442.0 \pm 3.4$ & $8.3 \pm 6.8$ \\
T6 & $68.1 \pm 0.9$ & $305.1 \pm 23.2$ & $27.3 \pm 9.5$ & $545.2 \pm 36.2$ & $33.2 \pm 2.8$ \\
T7 & $61.2 \pm 0.7$ & $246.0 \pm 19.8$ & $2.5 \pm 7.0$ & $389.7 \pm 19.4$ & $-4.7 \pm 0.3$ \\
T8 & $59.8 \pm 1.1$ & $181.4 \pm 32.4$ & $-25.3 \pm 5.4$ & $272.9 \pm 43.2$ & $-33.6 \pm 10.0$ \\
T9 & $58.1 \pm 0.9$ & $246.2 \pm 45.4$ & $1.2 \pm 8.2$ & $370.0 \pm 35.4$ & $-9.7 \pm 5.6$ \\
T10 & $60.2 \pm 1.0$ & $264.0 \pm 30.8$ & $9.5 \pm 1.8$ & $413.3 \pm 24.2$ & $1.0 \pm 0.9$ \\
\hline
\end{tabular}

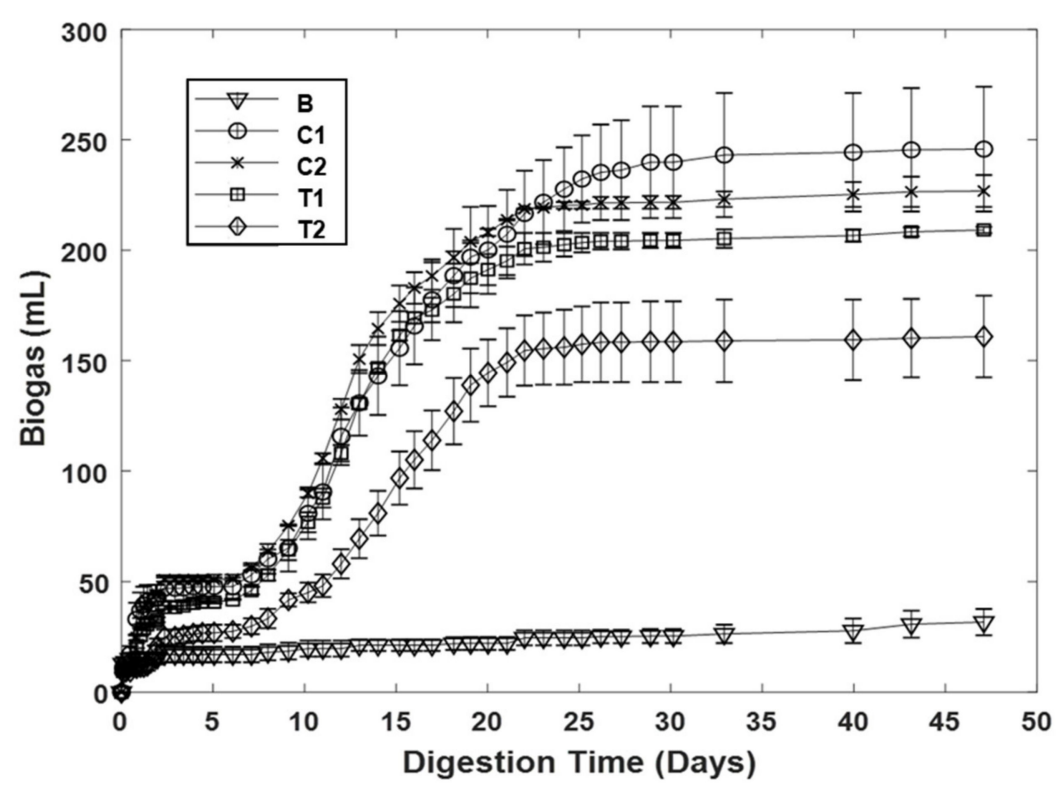

Figure 1. The effect of $20 \mathrm{~g} / \mathrm{L}$ biochar supplementation on biogas production in the absence and presence of trace metals at chemical oxygen demand (COD) of $4520 \mathrm{mg} / \mathrm{L}$. 


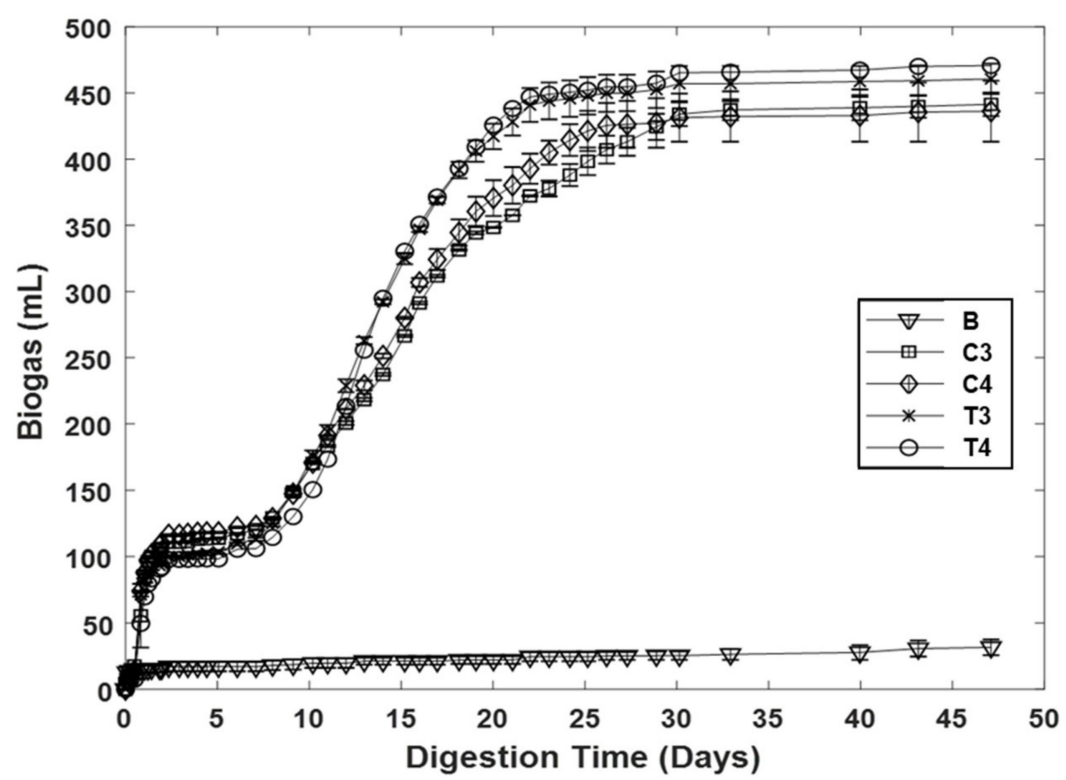

Figure 2. The effect of $20 \mathrm{~g} / \mathrm{L}$ biochar supplementation on biogas production in the absence and presence of trace metals at COD of $7264 \mathrm{mg} / \mathrm{L}$.

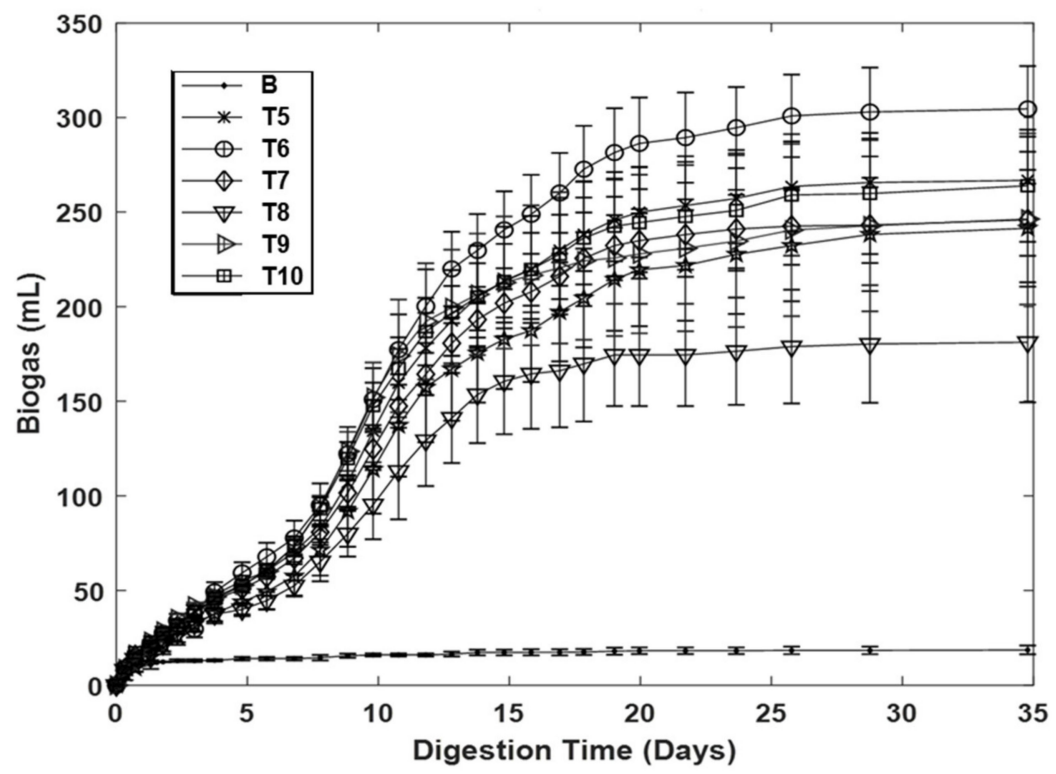

Figure 3. The effect of 2.0-10.0 g/L biochar and magnetite supplementation on biogas production in the presence of trace metals at COD of $7467 \mathrm{mg} / \mathrm{L}$.

Biogas production was observed right after incubation in reactors $\mathrm{C} 1-\mathrm{C} 4$ and $\mathrm{T} 1-\mathrm{T} 4$ at a high rate for the first two days. Then, it levelled off on Day 3 for five days. This can be explained by the low initial soluble COD of the feedstock and the need for hydrolysis and consecutive biogas production from the insoluble part of the organics later [32]. Beyond Day 8, a steady biogas production was observed in $\mathrm{C} 1-\mathrm{C} 4$ and T1-T2 until Day 22 and in T3-T4 until Day 26 (Figures 1 and 2). Then, the biogas production reduced gradually in all reactors (C1-C4 and T1-T4) for several more days and levelled off on Day 40 (Figures 1 and 2).

A high initial biogas production rate was also observed for reactors C5 and T5-T10 (Figure 3). However, unlike reactors $\mathrm{C} 1-\mathrm{C} 4$ and $\mathrm{T} 1-\mathrm{T} 4$, the biogas production did not level off after this high initial rate. On the contrary, an exponential increase was observed in the biogas production rate beyond Day 8. Then the biogas production in C5 and T5-T10 was stabilized on Day 29 (Figure 3). 
The total biogas production values for all reactors are depicted in Table 3. In order to evaluate the effect of different supplementations, the biogas values in test reactors were normalized relative to the control reactors that were identical to test reactors except for the supplementation of trace metals, biochar, and/or magnetite.

BMP tests are commonly used for the determination of the methane potential and biodegradability of different wastewater and waste biomass. Due to the biological nature of the assay and heterogeneity of the feedstocks, high standard deviation values up to $34 \%$ are reported [33,34]. Similarly, the normalized biogas production values obtained in this study are relatively high (up to $22.4 \%$, Table 3 ). However, the results still clearly indicate the effect of different supplementations on the AD process performance. As seen from Table 3, both biochar and magnetite supplementation improved the AD of FW. $20 \mathrm{~g} / \mathrm{L}$ of biochar supplementation increased the biogas production by $4.3 \pm 1.0 \%$ (T3, Table 3 ), while the methane yield for the same reactor decreased by $3.7 \pm 5.6 \%$. This inconsistency can be explained by experimental errors as reflected by high standard deviation values. Higher biochar doses were not investigated since biochar was reported to be inhibitory to $\mathrm{AD}$ at concentrations above $32 \mathrm{~g} / \mathrm{L}[35,36]$. A decrease in biochar dose to 2.0 and $5.0 \mathrm{~g} / \mathrm{L}$ resulted in $11.2 \pm 6.5$ and $27.3 \pm 9.5 \%$ increase, respectively ( $\mathrm{T} 5$ and $\mathrm{T} 6$, Table 3). On the other side, the improvement observed by the supplementation of magnetite was relatively lower compared to biochar for the same doses. Namely, 5.0 and $10.0 \mathrm{~g} / \mathrm{L}$ magnetite addition led to $1.2 \pm 8.2$ and $9.5 \pm 1.8 \%$ increase in biogas production relative to control reactors, respectively (T9 and T10, Table 3).

It must be noted at this point that even though the investigated biochar and magnetite concentrations are relatively high, they are produced from agricultural and food wastes as well as forestry residues [37-39]. Thus, their use in these concentration ranges would not translate to prohibitively high operational costs for the AD process.

\subsection{Methane Yields}

Methane yield, or the volume of methane produced per mass of volatile solids, is a commonly used parameter to assess the energy generation potential of several feedstocks. Moreover, methane yield offers a unified basis to compare different feedstock due to their varying levels of solids content $[39,40]$. Methane yields for the reactors operated in this study were calculated and presented in Table 3. Similar to the total biogas production values, methane yield values in test reactors were also normalized relative to the control reactors (Table 3 ).

The methane yields of reactors supplemented with trace metals, biochar, and/or magnetite ranged between $272.9 \pm 43.2-545.2 \pm 36.2 \mathrm{~mL} \mathrm{CH}_{4} / \mathrm{g}$ VS. These values are in agreement with the methane yield ranges of 160-350 and 460-530 $\mathrm{mL} \mathrm{CH}_{4} / \mathrm{g}$ VS reported for fruit and vegetable [41-44] and household and restaurant food waste $[3,40,41,45,46]$, respectively. Similar to the total biogas production values, biochar supplementation improved the AD of FW. Biochar dose to 2.0 and $5.0 \mathrm{~g} / \mathrm{L}$ resulted in $8.3 \pm 6.8$ and $33.2 \pm 2.8 \%$ increase, respectively (T5 and T6, Table 3). However, magnetite did not lead to a statistically significant improvement.

\subsection{Anaerobic Stabilization}

The AD of FW does not only serve for renewable energy generation in the form of methane but also the treatment or stabilization of FW for environmentally safe disposal. COD removal is the commonly used parameter to assess the level of treatment or stabilization of FW [15,29,43]. The AD was reported to be both an efficient technology for food waste treatment and disposal and a promising source of renewable energy [38,45-47]. COD removal ranged between $60.0 \pm 1.0-88.0 \pm 0 \%$ (Figure 4). The efficiency of COD removal during the AD of FW was reported to be $47-77 \%$ in the relevant literature $[40,42,47-50]$. Therefore, conductive material supplementation improved the COD removal efficiency along with biogas production and methane yield. 


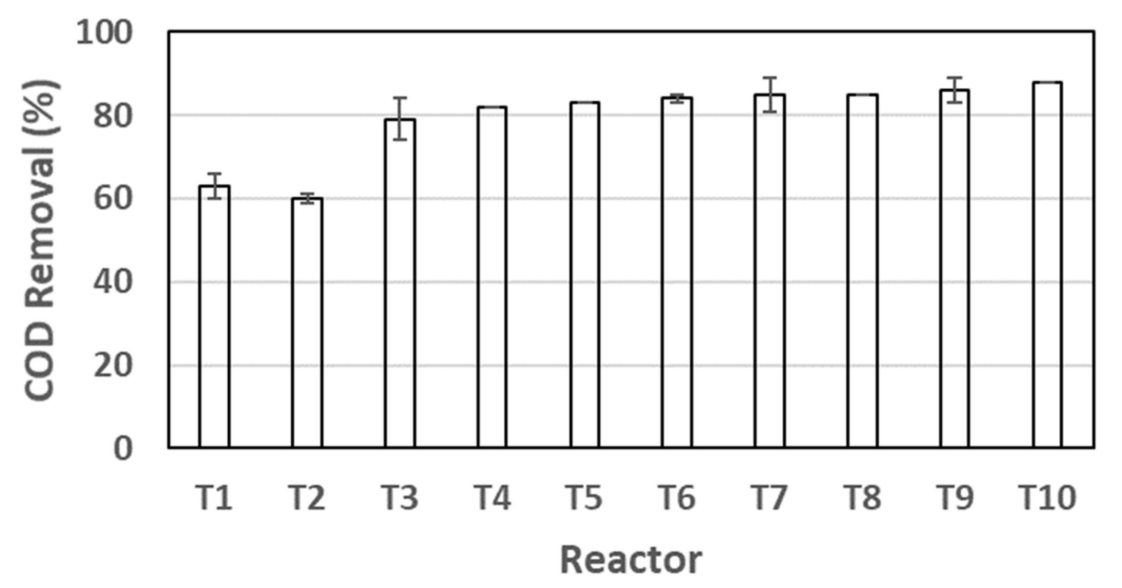

Figure 4. The COD removal efficiency observed in reactors.

\section{Conclusions}

The supplementation of biochar and trace metals were found to favor biogas production and methane yields. Namely, a biochar dose of 2.0 and $5.0 \mathrm{~g} / \mathrm{L}$ resulted in $11.2 \pm 6.5$ and $27.3 \pm 9.5 \%$ increase in biogas and $8.3 \pm 6.8$ and $33.2 \pm 2.8 \%$ increase in methane yield, respectively. The same reactors demonstrated high FW stabilization performance of over an 80\% COD removal efficiency. These results indicate that biochar supplementation leads to improved AD operation that could be through the increased surface area for microbial growth and/or the DIET mechanism. In turn, FW will not only be stabilized but also valorized by AD at higher efficiencies that support sustainable waste management through both environmentally safe disposal and value-added generation.

Author Contributions: A.S.A. conducted the experiments and collected data. A.S.A. and G.N.D. planned the research and designed the experiments, analyzed data and wrote the article. All authors have read and agreed to the published version of the manuscript.

Funding: This research was funded by Central Michigan University's Office of Research and Graduate Studies.

Acknowledgments: The authors are thankful to Daniel Zitomer (Marquette University) for providing the biochar used in the experiments and Sibel Uludag-Demirer (Michigan State University) for methane analyses.

Conflicts of Interest: The authors declare no conflict of interest.

\section{References}

1. Gustavvson, J.; Cederberg, C.; Sonesson, U.; van Otterdijk, R.; Meybeck, A. Global Food Losses and Food Waste: Extent, Causes and Prevention; FAO: Rome, Italy, 2011.

2. Food and Agriculture Organization of the United Nations (FAO). Food Wastage Footprint Impacts on Natural Resources; Food and Agriculture Organization of the United Nations: Rome, Italy, 2013; ISBN 978-92-5-107752-8.

3. Zhang, C.; Su, H.; Baeyens, J.; Tan, T. Reviewing the anaerobic digestion of food waste for biogas production. Renew. Sustain. Energy Rev. 2014, 38, 383-392. [CrossRef]

4. Lin, C.; Pfaltzgraff, L.; Herrero-Davila, L.; Mubofu, E.; Abderrahim, S.; Clark, J.; Koutinas, A.; Kopsahelis, N.; Stamatelatou, K.; Dickson, F.; et al. Food waste as a valuable resource for the production of chemicals, materials and fuels. Current situation and global perspective. Energy Environ. Sci. 2013, 6, 426-464. [CrossRef]

5. Posmanik, R.; Labatut, R.; Kim, A.; Usack, J.; Tester, J.; Angenent, L. Coupling hydrothermal liquefaction and anaerobic digestion for energy valorization from model biomass feedstocks. Bioresour. Technol. 2017, 233, 134-143. [CrossRef]

6. Mirabella, N.; Castellani, V.; Sala, S. Current options for the valorization of food manufacturing waste: A review. J. Clean. Prod. 2014, 65, 28-41. [CrossRef] 
7. Ngoc, B.D.T.; Chiu-Yue, L.; Gopalakrishnan, K. Waste-to-wealth for valorization of food waste to hydrogen and methane towards creating a sustainable ideal source of bioenergy. J. Clean. Prod. 2016, 122, $29-41$.

8. Alkaya, E.; Demirer, G.N. Minimizing and adding value to seafood processing wastes. Food Bioprod. Process. 2016, 100, 195-202. [CrossRef]

9. Tampio, E.; Ervasti, S.; Paavola, T.; Heaven, S.; Banks, C.; Rintala, J. Anaerobic digestion of autoclaved and untreated food waste. Waste Manag. 2014, 34, 370-377. [CrossRef] [PubMed]

10. Erguder, T.H.; Demirer, G.N. Organic acid production from the organic fraction of municipal solid waste and cow manure in leaching bed reactors. Environ. Eng. Manag. J. 2016, 15, 24-87, 2495.

11. Calicioglu, O.; Demirer, G.N. Biogas production from waste microalgal biomass obtained from nutrient removal of domestic wastewater. Waste Biomass Valorization 2016, 7, 1397-1408. [CrossRef]

12. Ramírez-Arpide, F.R.; Demirer, G.N.; Gallegos-Vázquez, C.; Hernández-Eugenio, G.; Santoyo-Cortés, V.H.; Espinosa-Solares, T. Life cycle assessment of biogas production through anaerobic co-digestion of nopal cladodes and dairy cow manure. J. Clean. Prod. 2018, 172, 2313-2322. [CrossRef]

13. Gur, E.; Demirer, G.N. Anaerobic digestibility and biogas production capacity of pistachio processing wastewater in UASB reactors. J. Environ. Eng. 2019, 145, 8. [CrossRef]

14. Ariunbaatar, J.; Panico, A.; Esposito, G.; Pirozzi, F.; Lens, P.N.L. Pre-treatment methods to enhance anaerobic digestion of organic solid waste. Appl. Energy 2014, 123, 143-156. [CrossRef]

15. Zhang, C.; Xiao, G.; Peng, L.; Su, H.; Tan, T. The anaerobic co-digestion of food waste and cattle manure. Bioresour. Technol. 2013, 129, 170-176. [CrossRef]

16. Zamanzadeh, M.; Hagen, L.H.; Svensson, K.; Linjordet, R.; Horn, S.J. Anaerobic digestion of food waste-Effect of recirculation and temperature on performance and microbiology. Water Res. 2016, 96, 246-254. [CrossRef] [PubMed]

17. Capson-Tojo, G.; Ruiz, D.; Rouez, M.; Crest, M.; Steyer, J.-P.; Bernet, N.; Delgenès, J.-P.; Escudié, R. Accumulation of propionic acid during consecutive batch anaerobic digestion of commercial food waste. Bioresour. Technol. 2017, 245, 724-733. [CrossRef]

18. Liu, F.; Rotaru, A.E.; Shrestha, P.M.; Malvankar, N.S.; Nevin, K.P.; Lovley, D.R. Promoting direct interspecies electron transfer with activated carbon. Energ. Environ. Sci. 2012, 5, 8982-8989. [CrossRef]

19. Cruz Viggi, C.; Rossetti, S.; Fazi, S.; Paiano, P.; Majone, M.; Aulenta, F. Magnetite particles triggering a faster and more robust syntrophic pathway of methanogenic propionate degradation. Environ. Sci. Technol. 2014, 48, 7536-7543. [CrossRef]

20. Dang, Y.; Holmes, D.E.; Zhao, Z.; Woodard, T.L.; Zhang, Y.; Sun, D.; Wang, L.; Nevin, K.P.; Lovley, D.R. Enhancing anaerobic digestion of complex organic waste with carbon-based conductive materials. Bioresour. Technol. 2016, 220, 516-522. [CrossRef]

21. Chen, S.; Rotaru, A.; Liu, F.; Philips, J.; Woodard, T.L.; Nevin, K.P.; Lovley, D.R. Carbon cloth stimulates direct interspecies electron transfer in syntrophic cocultures. Bioresour. Technol. 2014, 173, 82-86. [CrossRef]

22. Rotaru, A.E.; Shrestha, P.M.; Liu, F.; Markovaite, B.; Chen, S.; Nevin, K.P.; Lovley, D.R. Direct interspecies electron transfer between Geobacter metallireducens and Methanosarcina barkeri. Appl. Environ. Microbiol. 2014, 80, 4599-4605. [CrossRef]

23. Zhao, Z.; Zhang, Y.; Holmes, D.E.; Dang, Y.; Woodard, T.L.; Nevin, K.P.; Lovley, D.R. Potential enhancement of direct interspecies electron transfer for syntrophic metabolism of propionate and butyrate with biochar in up-flow anaerobic sludge blanket reactors. Bioresour. Technol. 2016, 209, 148-156. [CrossRef] [PubMed]

24. Cruz Viggi, C.; Simonetti, S.; Palma, E.; Pagliaccia, P.; Braguglia, C.; Fazi, S.; Baronti, S. Enhancing methane production from food waste fermentate using biochar: The added value of electrochemical testing in pre-selecting the most effective type of biochar. Biotechnol. Biofuels 2017, 10, 303. [CrossRef] [PubMed]

25. Ye, M.; Liu, J.; Ma, C.; Li, Y.; Zou, L.; Qian, G.; Xu, Z.P. Improving the stability and efficiency of anaerobic digestion of food waste using additives: A critical review. J. Clean. Prod. 2018, 192, 316-326. [CrossRef]

26. Banks, C.J.; Zhang, Y.; Jiang, Y.; Heaven, S. Trace element requirements for stable food waste digestion at elevated ammonia concentrations. Bioresour. Technol. 2012, 104, 127-135. [CrossRef]

27. Romero-Güiza, M.; Vila, J.; Mata-Alvarez, J.; Chimenos, J.; Astals, S. The role of additives on anaerobic digestion: A review. Renew. Sustain. Energy Rev. 2016, 58, 1486-1499. [CrossRef]

28. Voelklein, M.A.; O'Shea, R.; Jacob, A.; Murphy, J.D. Role of trace elements in single and two-stage digestion of food waste at high organic loading rates. Energy 2017, 121, 185-192. [CrossRef] 
29. Zhang, W.; Wu, S.; Guo, J.; Zhou, J.; Dong, R. Performance and kinetic evaluation of semi-continuously fed anaerobic digesters treating food waste: Role of trace elements. Bioresour. Technol. 2015, 178, 297-305. [CrossRef]

30. Baird, R.; Bridgewater, L. Standard Methods for the Examination of Water and Wastewater, 23rd ed.; American Public Health Association: Washington, DC, USA, 2017.

31. Achinas, S.; Euverink, G.J.W. Elevated biogas production from the anaerobic co-digestion of farmhouse waste: Insight into the process performance and kinetics. Waste Manag. Res. 2019, 37, 1240-1249. [CrossRef]

32. Zhao, M.X.; Ruan, W.Q. Biogas performance from co-digestion of Taihu algae and kitchen wastes. Energy Convers. Manag. 2013, 75, 21-24. [CrossRef]

33. Raposo, F.; Fernández-Cegrí, V.; De la Rubia, M.A.; Borja, R.; Béline, F.; Cavinato, C.; Demirer, G.; Fernández, B.; Fernández-Polanco, M.; Frigon, J.C.; et al. Biochemical methane potential (BMP) of solid organic substrates: Evaluation of anaerobic biodegradability using data from an international inter-laboratory study. J. Chem. Technol. Biotechnol. 2011, 86, 1088-1098. [CrossRef]

34. Pham, C.H.; Triolo, J.M.; Cu, T.T.T.; Pedersen, L.; Sommer, S.G. Validation and recommendation of methods to measure biogas production potential of animal manure. Asian-Australas J. Anim. Sci. 2013, 26, 864-873. [CrossRef] [PubMed]

35. Zhou, H.; Brown, R.C.; Wen, Z. Biochar as an additive in anaerobic digestion of municipal sludge: Biochar properties and their effects on the digestion performance. ACS Sustain. Chem. Eng. 2020, 8, 6391-6401. [CrossRef]

36. Linville, J.L.; Shen, Y.; Leon, P.A.I.; Schoene, R.P.; Urgun-Demirtas, M. In-situ biogas upgrading during anaerobic digestion of food waste amended with walnut shell biochar at bench scale. Waste Manag. Res. 2017, 35, 669-679. [CrossRef] [PubMed]

37. Alberto, D.R.; Repa, K.S.; Hegde, S.; Miller, C.W.; Trabold, T.A. Novel production of magnetite particles via thermochemical processing of digestate from manure and food waste. IEEE Magn. Lett. 2019, 10, 1-5. [CrossRef]

38. Thines, K.; Abdullah, E.; Mujawar, M.; Ruthiraan, M. Synthesis of magnetic biochar from agricultural waste biomass to enhancing route for wastewater and polymer application: A review. Renew. Sustain. Energy Rev. 2017, 67, 257-276. [CrossRef]

39. Yang, X.; Zhang, S.; Ju, M.; Liu, L. Preparation and modification of biochar materials and their application in soil remediation. Appl. Sci. 2019, 9, 1365. [CrossRef]

40. Brown, D.; Li, Y. Solid state anaerobic co-digestion of yard waste and food waste for biogas production. Bioresour. Technol. 2013, 127, 275-280. [CrossRef]

41. Meng, Y.; Li, S.; Yuan, H.; Zou, D.; Liu, Y.; Zhu, B.; Chufo, A.; Jaffar, M.; Li, X. Evaluating biomethane production from anaerobic mono- and co-digestion of food waste and floatable oil (FO) skimmed from food waste. Bioresour. Technol. 2015, 185, 7-13. [CrossRef]

42. Labatut, R.; Angenent, L.T.; Scott, N. Biochemical methane potential and biodegradability of complex organic substrates. Bioresour. Technol. 2011, 102, 2255-2264. [CrossRef]

43. Lin, J.; Zuo, J.; Gan, L.; Li, P.; Liu, F.; Wang, K.; Chen, L.; Gan, H. Effects of mixture ratio on anaerobic co-digestion with fruit and vegetable waste and food waste of China. J. Environ. Sci. 2011, 23, 1403-1408. [CrossRef]

44. Shen, F.; Yuan, H.; Pang, Y.; Chen, S.; Zhu, B.; Zou, D.; Liu, Y.; Ma, J.; Yu, L.; Li, X. Performances of anaerobic co-digestion of fruit \& vegetable waste (FVW) and food waste (FW): Single-phase vs. two-phase. Bioresour. Technol. 2013, 144, 80-85. [PubMed]

45. Agyeman, F.; Tao, W. Anaerobic co-digestion of food waste and dairy manure: Effects of food waste particle size and organic loading rate. J. Environ. Manag. 2014, 133, 268-274. [CrossRef] [PubMed]

46. Zhen, G.; Lu, X.; Kobayashi, T.; Kumara, G.; Xu, K. Anaerobic co-digestion on improving methane production from mixed microalgae (Scenedesmus sp., Chlorella sp.) and food waste: Kinetic modeling and synergistic impact evaluation. Chem. Eng. J. 2016, 299, 332-341. [CrossRef]

47. Meyer-Kohlstock, D.; Haupt, T.; Heldt, E.; Heldt, N.; Kraft, E. Biochar as additive in biogas-production from bio-waste. Energies 2016, 9, 247. [CrossRef]

48. Xu, F.; Li, Y.; Ge, X.; Yang, L.; Li, Y. Anaerobic digestion of food waste-Challenges and opportunities. Bioresour. Technol. 2018, 247, 1047-1058. [CrossRef] 
49. Latif, M.A.; Ahmad, A.; Ghufran, R.; Wahid, Z.A. Effect of temperature and organic loading rate on upflow anaerobic sludge blanket reactor and $\mathrm{CH}_{4}$ production by treating liquidized food waste. Environ. Prog. Sustain. Energy 2012, 31, 114-121. [CrossRef]

50. Chan, P.C.; de Toledo, R.A.; Shim, H. Anaerobic co-digestion of food waste and domestic wastewater-Effect of intermittent feeding on short and long chain fatty acids accumulation. Renew. Energy 2018, 124, 129-135. [CrossRef]

(C) 2020 by the authors. Licensee MDPI, Basel, Switzerland. This article is an open access article distributed under the terms and conditions of the Creative Commons Attribution (CC BY) license (http://creativecommons.org/licenses/by/4.0/). 